\title{
Assessment of facial profile changes in patients treated with maxillary premolar extractions
}

\author{
Renata Rodrigues de Almeida-Pedrin', Luciane Brigueli Marrone Guimarães², Marcio Rodrigues de Almeida, \\ Renato Rodrigues de Almeida ${ }^{4}$, Fernando Pedrin Carvalho Ferreira ${ }^{5}$
}

Objective: Evaluate the facial profile changes of orthodontic treatment with extraction of two upper first premolars, from the perspective of orthodontists, dentists and lay people. Methods: Facial profiles of radiographs taken before and after treatment of 70 patients with Class II, division 1 malocclusion were traced. The silhouettes of the 70 patients were randomly assembled in an album with, being two profiles on each sheet of the same patient. Then, 30 orthodontists, 30 dentists and 30 lay people chose the more esthetic facial profile (A or B), and the amount of change they perceived between the two profiles before and after treatment, according to a visual analog scale (VAS). Results: The results revealed that 83 examiners preferred the posttreatment profiles, and only three dentists and four lay people chose the profiles pre-treatment more frequently. Thus, the orthodontists often chose the profiles after treatment, followed by dentists, with no statistically significant differences found between dentists and lay people. There were significant differences within groups in the preference of pre- and post-treatment profile. Furthermore, the three groups of evaluators indicated that pre and post-treatment profiles did not differ substantially. Conclusions: The treatment of Class II, division 1 malocclusion with extraction of two first premolars has a positive effect on facial profile esthetics.

Keywords: Tooth extraction. Angle Class II malocclusion. Corrective orthodontics. Perception.

Objetivo: avaliar as alterações do perfil facial decorrentes do tratamento ortodôntico com extrações de dois primeiros pré-molares superiores, sob a óptica de ortodontistas, cirurgiões-dentistas e leigos. Métodos: foram traçados os perfis faciais das telerradiografias pré- e pós-tratamento de 70 pacientes com má oclusão de Classe II, divisão 1, e foi montado um álbum com as silhuetas dos 70 pacientes, de forma aleatória, sendo dois perfis em cada folha do mesmo paciente. A seguir, 30 ortodontistas, 30 cirurgiões-dentistas e 30 leigos escolheram o perfil facial mais estético (A ou B), e a quantidade de alteração que percebiam entre os dois perfis pré- e pós-tratamento, de acordo com a escala visual analógica (EVA). Resultados: os resultados revelaram que 83 examinadores preferiram o perfil pós-tratamento, sendo que somente três cirurgiões-dentistas e quatro leigos escolheram com maior frequência os perfis pré-tratamento. Assim, os ortodontistas escolheram mais frequentemente os perfis pós-tratamento, seguidos pelos cirurgiões-dentistas, sem diferença estatisticamente significativa entre cirurgiões-dentistas e leigos. Houve diferença estatisticamente significativa intragrupos na preferência do perfil pré- e pós-tratamento. Além disso, os três grupos de avaliadores indicaram que os perfis pré- e pós-tratamento não diferiram substancialmente. Conclusões: o tratamento da má oclusão de Classe II, divisão 1, com extração de dois primeiros pré-molares produziu um efeito positivo na estética do perfil facial.

Palavras-chave: Extração dentária. Má oclusão Classe II de Angle. Ortodontia corretiva. Percepção.

${ }^{1}$ Post-Doc in Orthodontics, FOB-USP. Professor, Graduation and Post-Graduation in Dentistry, USC-Bauru

${ }^{2}$ Specialist in Orthodontics.

${ }^{3}$ Post-Doc in Orthodontics, FOB-USP. Professor of Post-Graduation, UNOPAR.

${ }^{4}$ Full Professor. PhD in Orthodontics and Public Health, USP. Professor of PostGraduation in Dentistry, UNOPAR.

${ }^{5} \mathrm{PhD}$ in Orthodontics, USP.

" The authors report no commercial, proprietary or financial interest in the products or companies described in this article.
How to cite this article: Almeida-Pedrin RR, Guimarães LBM, Almeida MR, Almeida RR, Ferreira FPC. Assessment of facial profile changes in patients treated with maxillary premolar extractions. Dental Press J Orthod. 2012 Sept-Oct;17(5):131-7.

Submitted: November 16, 2009 - Revised and accepted: July 08, de 2012

Contact address: Renata Rodrigues de Almeida-Pedrin

E-mail: renatinhaalmeida@uol.com.br 


\section{INTRODUCTION}

For years, orthodontists have studied the soft tissue profile in patients treated orthodontically, seeking facial harmony, and the correct dental positioning. ${ }^{16}$ In the past, the esthetic facial profile was described very subjectively, and the concept of beauty would refer to the figure of the Greek God Apollo of Belvedere. But, the standards of beauty have changed possibly due to the mixing of races, global media, customs, religion and age; with stronger traits than the straight lines from the Greeks.

Facial appearance plays an important role when judging the self-attractiveness and also the development of self-esteem. ${ }^{18}$ The perception of appearance, especially of the face, affects mental health and social behavior with significant implications in the educational and professional areas, as well as in the emotional life. ${ }^{14}$

The Class II malocclusion may affect facial harmony in various degrees, according to the intensity of dental overjet and its interaction with the soft tissues, interfering with the image and self-esteem of the patient. ${ }^{1}$ Thus, the treatment of malocclusions is important for the social inclusion of the patient and it is of great interest to orthodontists, and the demand for treatment is significant in clinical orthodontic. This malocclusion is presented as the most common in orthodontic clinics around the world, reaching rates of $55 \% .^{7}$

Among the different treatments of Class II, Division 1 , there is an alternative therapy, the extraction of two upper first premolars. ${ }^{5,24}$ The debate on extractions has lasted for many years and there are researchers in favor of no extraction, because they think that this form of treatment tends to flatten the face (with retruded lips). On the other hand, those in favor of extraction, assume that in the treatment without extraction lips are too protruded due to protruded incisors. ${ }^{23}$

The literature on the extraction dilemma in orthodontics is abundant and most studies show little soft tissue post-treatment alterations in patients with and without extractions. ${ }^{2,12}$ Although cephalometric studies exhibit differences mainly in dento-skeletal components among patients treated with and without extraction, an important point would be to check the effect of these therapies in facial esthetics under the point of view of orthodontists, dentists and lay people, since the studies in this area are scarce.

The search for a balanced facial profile is a constant challenge for orthodontists, who continue to debate the extraction issue to improve dento-skeletal relations. However, the literature is still short on the effects of extraction of two first premolars in facial esthetic profile in patients with Class II.

Therefore, knowledge about the possibilities of changes in facial profile resulting from this treatment protocol is necessary for professionals in Orthodontics.

This work aimed to evaluate the facial profile changes from orthodontic treatment with extraction of two upper first premolars, from the perspective of orthodontists, dentists and lay people.

\section{MATERIAL AND METHODS}

The sample consisted of 140 lateral cephalograms of 70 young Brazilians of both genders from the collection of the Centro Dental de Almeida Rodrigues - CORA. The lateral cephalometric radiographs were obtained in the same X-ray device before installation and after removal of the appliance. The criteria for sample selection were based on the following characteristics:

1) Young patients showed initial Class II malocclusion of dentoalveolar origin, without skeletal compromise, assessed clinically and by means of study casts.

2) Caucasian, Italian, Portuguese and Spanish descendants.

3) Lack of agenesis or loss of permanent teeth.

4) Treated with extraction of two upper first premolars.

The 70 patients, 38 females and 22 males with Class II malocclusion, were treated with orthodontic pre-adjusted appliances (Straight Wire) Andrews prescription and $0.022 \times 0.030$-in slot followed by extractions only in the upper arch (first premolars). All patients used transpalatal bar (TPA) in the first upper molars. The leveling of the dental arches was obtained with nickel titanium wire 0.014-in, 0.016-in, $0.016 \times 0.022$-in and 0.019 x 0.025-in. After alignment and leveling stainless steel arches were installed 0.019. x 0.025-in with hooks on the mesial of maxillary canines and the retraction of the anterior block was performed 
with sliding mechanics. After closing the spaces the intercuspation and finishing was obtained with $0.019 \times 0.025$-in braided stainless steel arches. The appliances were removed after obtaining Class I canine occlusion, complete correction of overjet, overbite and tooth alignment.

Characteristics such as age of patients and duration of treatment are shown in Table 1.

\section{Methods}

After obtaining the lateral radiographs, we proceeded to the preparation of cephalograms and handouts. The tracings were performed by a single researcher (LBM) and checked by another (RRAP) in a darkened room, for identification of anatomical structures. Only the soft tissue profile silhouette was traced with a lead pencil on a $0.5 \mathrm{~mm}$ HB acetate paper "Ultraphan" $0.07 \mathrm{~mm}$ thick and $17.5 \mathrm{~mm}$ width and length, adjusted to the radiographs (Fig 1 ).

The tracings were scanned to the computer and a task of completing the profile was done in Corel Draw by a single computer technician. The two profiles (pretreatment) and (post- treatment) were inserted for each patient on the same sheet, but in a random order, ie, the initial profile could be to the right or left of the sheet (Fig 2). Thus, it was possible to assemble an album with all the silhouettes of the 70 patients.
Table 1 - Mean, minimum and maximum values of initial and final ages, and treatment duration.

\begin{tabular}{cccc} 
Variable & Mean value & Minimum value & Maximum value \\
\hline Initial age & $15.33^{\mathrm{a}}$ & $12^{\mathrm{A}}$ & $29.25^{\mathrm{A}}$ \\
Final age & $18.15^{\mathrm{a}}$ & $13.17^{\mathrm{A}}$ & $32.67^{\mathrm{A}}$ \\
$\begin{array}{c}\text { Treatment } \\
\text { period }\end{array}$ & $2.85^{\mathrm{a}}$ & $1.08^{\mathrm{A}}$ & $4.25^{\mathrm{A}}$ \\
\hline
\end{tabular}

\section{Examiners and assessment method}

A group of 90 evaluators participated in the survey in order to judge the profiles of each patient.

The evaluators were divided into three distinct groups:

" Orthodontists group: Comprised of 30 specialists in Orthodontics, 16 females and 14 males, mean age of 31.03 years.

" Dentists group: Consisting of 30 dentists with no orthodontic training, 18 females and 12 males, mean age of 38.96 years.

" Lay group: Comprised of 30 people with no dental knowledge, classified as lay in the area. In this group, 12 were male and 18 female and the mean age was 33.63 years.

Each evaluator received an album containing the profiles of 70 patients with two profiles on each sheet (pre- and post-treatment of the same patient).

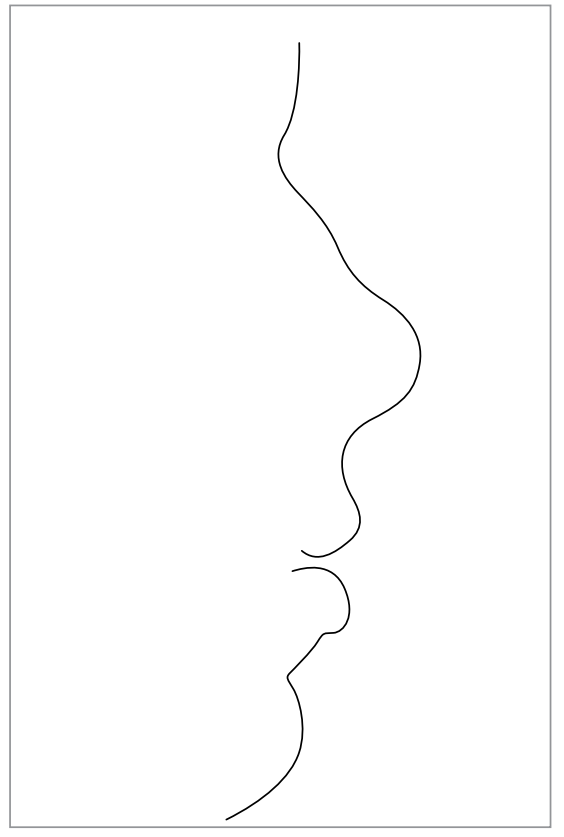

Figure 1 - Anatomical drawing of the soft tissue profile.

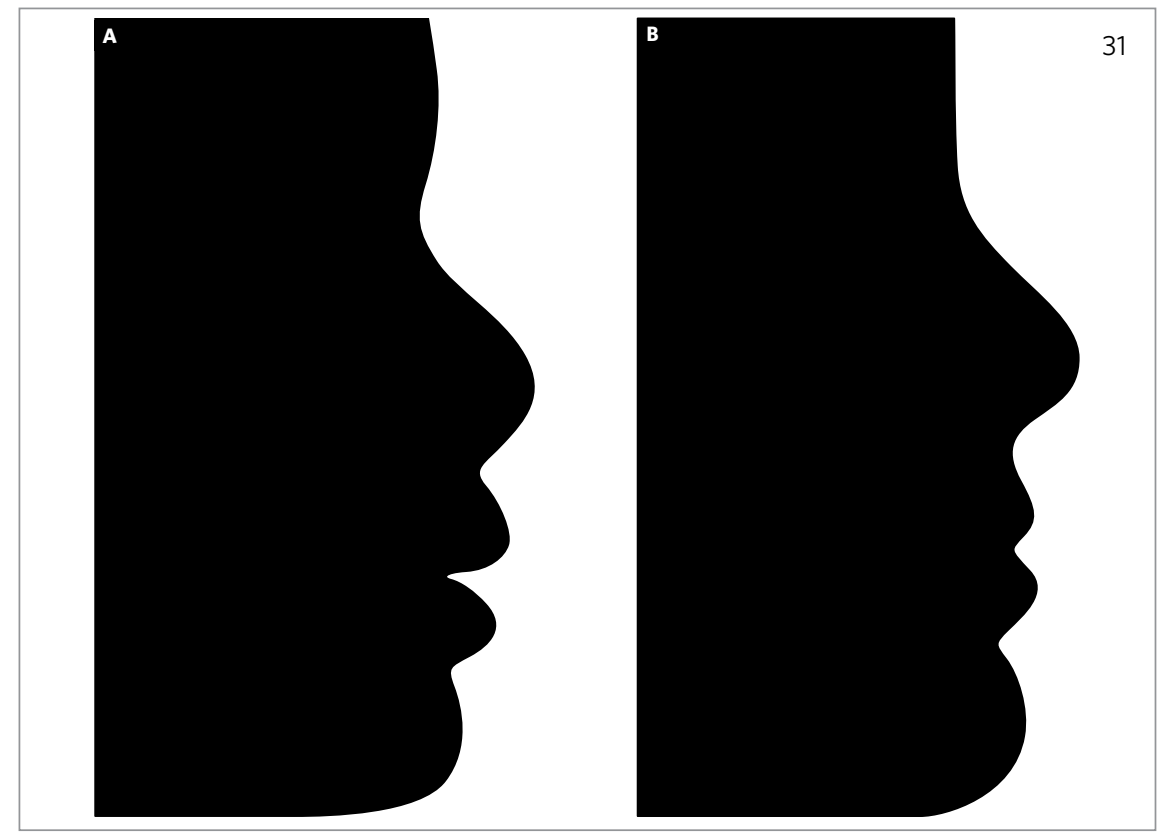

Figure 2 - Silhouette of profiles pre-and post-treatment from the patient number 31. 
Along with the album, the evaluators received instructions on how to answer, and a sheet for scores, in which the category to which they belonged to should be marked (layman, orthodontist or dentist), as well as gender and age. They were asked to indicate their preferences in relation to the profile (A or B) and the amount of change they perceived between the two profiles, according to a visual analog scale (VAS).

The visual analog scale used was characterized by a $100 \mathrm{~mm}$ line, where the demarcation at zero, at the left end, meant that the profiles contained in the same sheet were the same and in the opposite extreme, in the right end, that they were very different.

\section{Statistical analysis}

In order to verify the degree of similarity between the groups with regard to profile preferences pre- or post-treatment, a comparison was carried out by an analysis of variance test (ANOVA) and when statistically significant differences were found between the groups, the Tukey test was used.

In order to verify within-group differences in choosing the profile pre-or post-treatment, we used the paired $t$ test.

To check the amount of noticeable difference between the pre- and post-treatment profiles resulting from the values attributed to the visual analogue scale the analysis of variance (ANOVA) was used, followed by Tukey's test. In all analyses employed statistically significant results were considered for $\mathrm{p} \leq 0.05$ and $\mathrm{p} \leq 0.001$.

\section{RESULTS}

The results showed that the three groups of evaluators preferred more often the profiles after orthodontic treatment (Table 2).

Only seven people, four belonging to the lay group and three from the dentists group, chose the profiles pre-treatment more often. All other reviewers (83) preferred the post-treatment profiles (Fig 1).

In order to verify the degree of similarity between the groups of evaluators, in relation to the profile preferences for pre or post-treatment comparison was carried out using the ANOVA analysis (Table 3). The comparison results indicated statistically significant differences between groups, being the group of orthodontists the one that more often chose the profiles after treatment, followed by dentists and finally, the laymen.

In order to verify intragroup differences in choosing the pre- or post-treatment profile, the paired $t$ test was used (Table 4). In evaluating preferences, assuming a total of 70 patients, orthodontists chose 27 profiles pre- and 43 profiles post-treatment, the dentists 29 pre and 41 post-treatment and the lay people chosen 30 pre and 40 post-treatment and this difference was statistically significant.

To quantify the pre- and post-treatment profiles the visual analogue scale was used and then the results were submitted to the analysis of variance to see if there was agreement among the examiners (Table 5). According to the VAS scale, the mean values assigned by orthodontists, dentists and by the laymen were not statistically significant different $(p=0.37)$. Although the evaluators had chosen, in most cases, the after treatment profile, they indicated that it did not differ substantially.

Table 2 - Evaluation of profile preferences (pre- and post-treatment) by three groups of examiners.

\begin{tabular}{ccccc} 
GROUP & $\begin{array}{c}\text { Pre-treatment } \\
\text { Preference }\end{array}$ & $\begin{array}{c}\text { Post-treatment } \\
\text { preference }\end{array}$ & $\begin{array}{c}\text { Total of } \\
\text { patients }\end{array}$ & $\mathbf{p}$ \\
\hline Orthodontists & 27 & 43 & 70 & $0.00^{\star \star}$ \\
Dentists & 29 & 41 & 70 & $0.00^{\star \star}$ \\
Lay people & 30 & 40 & 70 & $0.00^{\star \star}$ \\
\hline * Significant for $\mathrm{p} \leq 0.05 .{ }^{* *}$ Significant for $\mathrm{p} \leq 0.01$. & &
\end{tabular}

Table 3 - Results from the analysis of variance (ANOVA) applied to the profile preference among the three groups of evaluators.

\begin{tabular}{|c|c|c|c|c|c|c|}
\hline \multirow{2}{*}{ Preference \% } & Orthodontist & Dentist & Lay people & \multicolumn{3}{|c|}{ ANOVA-P } \\
\hline & (1) & (2) & (3) & $1-2$ & $1-3$ & $2-3$ \\
\hline Pre-treatment & $38.04 \%$ & $42.23 \%$ & $43.14 \%$ & $0.03^{\star}$ & $0.00^{\star \star}$ & 0.85 \\
\hline Post-treatment & $61.95 \%$ & $57.76 \%$ & $56.85 \%$ & $0.03^{\star}$ & $0.00^{\star \star}$ & 0.85 \\
\hline
\end{tabular}

* Significant for $p \leq 0.05 .{ }^{\star \star}$ Significant for $p \leq 0.01$. 


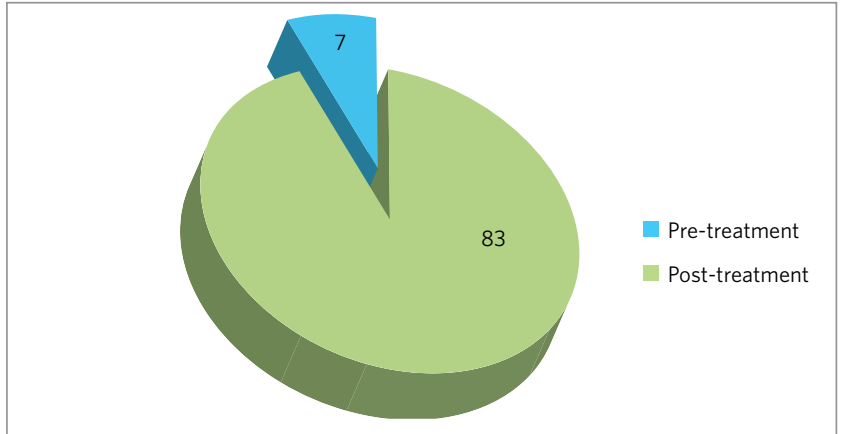

Figure 3 - Distribution of preferences of examiners $(n=90)$.

Table 4 - Results from the paired t test applied by within-group preference profile before and after treatment.

\begin{tabular}{ccccc} 
Group & $\begin{array}{c}\text { Pre- } \\
\text { treatment } \\
\text { preference }\end{array}$ & $\begin{array}{c}\text { Post-treatment } \\
\text { preference }\end{array}$ & $\begin{array}{c}\text { Total of } \\
\text { patients }\end{array}$ & $\mathbf{p}$ \\
\hline Orthodontists & 27 & 43 & 70 & $0.00^{* *}$ \\
Dentists & 29 & 41 & 70 & $0.00^{* *}$ \\
Lay people & 30 & 40 & 70 & $0.00^{* *}$ \\
\hline
\end{tabular}

* Significant for $p \leq 0.05 .{ }^{\star \star}$ Significant for $p \leq 0.01$.

Table 5 - Results from the analysis of variance applied to the visual analogue scale (VAS)

\begin{tabular}{ccccccc} 
Mean & Orthodontists & Dentists & Lay & \multicolumn{3}{c}{ ANOVA-p } \\
& (1) & (2) & (3) & $\mathbf{1 - 2}$ & $\mathbf{1 - 3}$ & $\mathbf{2 - 3}$ \\
\hline \multirow{2}{*}{ VAS } & 4.65 & 4.75 & 5.02 & $\begin{array}{c}0.93 \\
\mathrm{~ns}\end{array}$ & $\begin{array}{c}0.36 \\
\mathrm{~ns}\end{array}$ & $\begin{array}{c}0.57 \\
\mathrm{~ns}\end{array}$ \\
\hline
\end{tabular}

\section{DISCUSSION}

The evaluation of the changes introduced by orthodontic treatment in the facial profile of patients treated with extraction of two upper first premolars generates considerable interest. ${ }^{2}$ It is known that extraction of premolars is often chosen as alternative ${ }^{4}$ for the treatment of patients with Class II division 1 malocclusion, once they no longer present significant growth and have more severe overjet. However, studies on the effect of this treatment on the soft tissue are scarce.

The results of this study provided an insight regarding the perception of orthodontists, dentists and lay people about the amount of changes in the profiles before and after treatment in patients with Class II division 1 malocclusions. The results revealed that eighty-three evaluators of the three groups preferred
Profile preference pre or post-treament

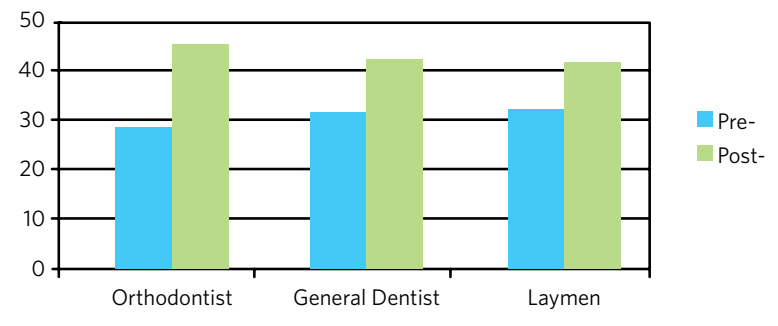

Figure 4 - Within-group comparison pre-and post-treatment.

the post-treatment profile and only three dentists and four lay people chose the pre-treatment profiles more often. On the preferences average, considering a total of 70 patients, orthodontists chose 27 pretreatment profiles and 43 post-treatment profiles, the dentists 29 pre and 41 post-treatment and laymen 30 pre and 40 post-treatment (Table 2 ).

Thus, in the opinion of the evaluators, treatment with extraction of first upper premolars produced a positive effect on soft tissue profile, for they chose the profiles after treatment more often. From this we can infer that this type of treatment has a beneficial effect on the esthetics of the facial profile.

Our results showed differences between the groups of evaluators in the preference after treatment, statistically significant difference in the profile evaluation performed by orthodontists (61.95\%), compared with the group of dentists (57.76\%) and laymen (56.85\%), but no statistically significant difference between dentists and lay people. The analysis of variance (ANOVA) denoted agreement between the choices of dentists and lay people $(p=0.85)$, but a disagreement with orthodontists $(p=0.03$ and $p=0.00$, respectively). Thus it is clear that the higher the degree of information of the evaluator in the specific area, the greater the degree of criterion.

Similar results, regarding the discrepancy between orthodontists and lay people in the area, are observed in several studies. In a study ${ }^{15}$ on the preference of the soft tissue profile in young Caucasian, African and Asian descendents, the author did not observe correlation between the evaluators' opinions (orthodontists, laymen and artists), demonstrating that the esthetic criteria, besides being subjective, are also personal. Another research ${ }^{17}$ carried out in order to assess 
facial profile preferences for the anteroposterior position of the mandible showed that the preference of orthodontists also differed in relation to both lay groups (Caucasian and Japanese). Disagreements were also observed between orthodontist evaluators in studies of facial attractiveness, ${ }^{10,11}$ showing that lay people were less careful in the assessment of this issue. The results of studies ${ }^{2,3}$ on the effect of treatment with and without extraction showed that orthodontists demonstrated a more accurate perception of small changes in facial profile. Moreover, in a study ${ }^{22}$ assessing the importance of the soft profile in esthetic, when lay and orthodontists were compared, it was found that orthodontists took into greater consideration the facial profile than lay people in the evaluation of facial esthetics. In researches ${ }^{25,13}$ on profile preference of the Turkish population and black women, respectively, there were statistically significant differences between the judgments of laypeople and orthodontists.

Disagreeing with the results of this study, it was observed that ${ }^{23}$ orthodontists and laypeople perceived similarity between the profile changes after treatment. Contrary also to the results of this research, another work ${ }^{21}$ did not denote significant differences between orthodontists and dentists. In researches ${ }^{6,19.20}$ on the profile preference the authors indicated that all groups of evaluators were consistent in the judgment of the profiles. In the work ${ }^{16}$ on ratings of profile attractiveness after treatment with functional appliances, the three groups of evaluators (dental students, arts students and parents of patients), showed no difference in their judgments.

The results denote statistically significant differences within-groups, with a predominant choice for the facial profile after treatment in all groups. Thus, orthodontists preferred 43 pre-treatment profiles and 27 post-treatment indicating statistically significant differences in this evaluation $(p=0.00)$. The same occurred with the dentists who chose more $(\mathrm{p}=0.00)$ profiles after treatment (41) in relation to pre-treatment (29) and with the lay people, who had a preference of 40 post-treatment and 30 pre-treatment profiles $(\mathrm{p}=0.00)$.
The visual analog scale was used in this study to quantify the perception of evaluators in relation to the amount of similarities or differences between the facial profiles before and after treatment. This method was endorsed by several investigators ${ }^{4,8,9,16,19,23}$ because of its simplicity and speed, being easily understood by the examiners and widespread in literature. In this study the VAS scale was characterized as a $100 \mathrm{~mm}$ line, where zero represented that profiles contained in the same sheet were the same and in the opposite extreme, that they were very different.

The results from the evaluation of this scale were subjected to analysis of variance (ANOVA) to determine whether there was agreement between the values assigned by the three groups of evaluators. These profiles indicated that pre and posttreatment did not differ significantly, however, were not classified as the same. According to the VAS scale, the mean values assigned by the orthodontists was $4.65 \mathrm{~mm}$, by the dentists was $4.75 \mathrm{~mm}$ and $5.02 \mathrm{~mm}$ by the lay people, with no statistically significant difference between them $(p=0.37)$. Thus, although most reviewers have chosen the post-treatment profile, they did not identify major differences between the profiles before and after treatment.

Considering the results of this survey, it is noted that the assessment of facial profile should be a continuous learning process for orthodontists, since patients are increasingly concerned about the effect that orthodontic treatment can induce in facial esthetics. The opinion of patients should always be mandatory in orthodontic planning.

\section{CONCLUSION}

Based on the methods and analysis of results, it was possible to concluded that orthodontic treatment of Class II, division 1 malocclusion with extraction of two first upper premolars had a positive effect on facial profile esthetics, since orthodontists, dentists and lay people preferred the large majority of the profiles after orthodontic treatment. 


\section{REFERENCES}

1. Almeida-Pedrin RR, Pinzan A, Almeida RR, Almeida MR, Henriques JFC. Efeitos do AEB conjugado e do Bionator no tratamento da Classe II, 1a divisão. R Dental Press Ortodon Ortop Facial. 2005 Out;10(5):37-54.

2. Bishara SE, Jakobsen JR. Profile changes in patients treated with and without extractions: Assessments by lay people. Am J Orthod Dentofacial Orthop. 1997 Dec;112(6):639-44

3. Boley JC, Pontier JP, Smith S, Fulbright M. Facial changes in extration and nonextraction patients. Angle Orthod. 1998 Dec;68(6):539-46.

4. Bowman SJ, Johnston LE Jr. The esthetic impact of extraction and nonextraction treatments on Caucasion patients. Angle Orthod. 2000 Feb;70(1):3-10.

5. Scott Conley $R$, Jernigan C. Soft tissue changes after upper premolar extraction in Class II camouflage therapy. Angle Orthod. 2006 Jan;76(1):59-65.

6. Foster EJ. Profile preferences among diversified groups. Angle Orthod. 1973 Jan;43(1):34-40.

7. Freitas MR, Freitas DS, Pinheiro FHSL, Freitas KMS. Prevalência das más oclusões em pacientes inscritos para tratamento ortodôntico na Faculdade de Odontologia de Bauru-USP. Rev Fac Odont Bauru. 2002;10(3):164-9.

8. Hall D, Taylor RW, Jacobson A, Sadowsky PL, Bartolucci A. The perception of optimal profile in African Americans versus white Americans as assessed by orthodontists and lay public. Am J Orthod Dentofacial Orthop. 2000 Nov;118(5):514-25.

9. Howells DJ, Shaw WC. The validity and reliability of ratings of dental and facial attractiveness for epidemiologic use. Am J Orthod. 1985 Nov;88(5):402-8.

10. Kerr WJS, O Donnell JM. Panel perception of facial attractiveness. Brit J Orthod. 1990 Nov;17(4):299-304

11. Knight H, Keith O. Ranking facial attractiveness. Eur J Orthod. 2005 Aug;27(4):340-8.

12. Kocadereli I. Changes in soft tissue profile after orthodontic treatment with and without extractions. Am J Orthod Dentofacial Orthop. 2002 Jul;122(1):67-72

13. McKoy-White J, Evans CA, Viana G, Anderson NK, Giddon DB. Facial profile preferences of black women before and after orthodontic treatment. Am J Orthod Dentofacial Orthop. 2006 Jan;129(1):17-23.
14. Mejia-Maidl M, Evans CA, Viana G, Anderson NK, Giddon DB. Preferences for facial profiles between Mexican Americans and Caucasians. Angle Orthod. 2005 Nov;75(6):953-8

15. Okuyama CC. Preferência do perfil facial tegumentar, em jovens leucodermas, melanodermas e xantodermas de ambos os sexos, avaliados por ortodontistas, leigos e artistas plásticos [Dissertação]. Bauru (SP): Universidade de São Paulo, Faculdade de Odontologia de Bauru; 1995. 94 p

16. O'Neill K, Harkness M, Knight R. Ratings of profile attractiveness after functional appliance treatment. Am J Orthod Dentofacial Orthop. 2000 Oct;118(4):371-6; discussion 377

17. Orsini MG, Huang GJ, Kiyak HA, Ramsay DS, Bollen AM, Anderson NK, et al. Methods to evaluate profile preferences for the anteroposterior position of the mandible. Am J Orthod Dentofacial Orthop. 2006 Sep;130(3):283-91.

18. Reis ASB, Abrão J, Capelozza Filho L, Claro CAA. Análise facial subjetiva. R Dental Press Ortodon Ortop Facial. 2006 Set-Out;11(5):159-72.

19. Schlosser JB, Preston CB, Lampasso J. The effects of computer-aided anteroposterior maxillary incisor movement on ratings of facial attractiveness. Am J Orthod Dentofacial Orthop. 2005 Jan;127(1):17-24.

20. De Smit A, Dermaut L. Soft-tissue profile preference. Am J Orthod. 1984 Jul;86(1):67-73.

21. Soh J, Chew MT, Wong HB. Professional assessment of facial profile attractiveness. Am J Orthod Dentofacial Orthop. 2005 Aug;128(2):201-5.

22. Spyropoulos MN, Halazonetis DJ. Significance of the soft tissue profile on facial esthetics. Am J Orthod Dentofacial Orthop. 2001 May;119(5):464-71.

23. Stephens CK, Boley JC, Behrents RG, Alexander RG, Buschang PH. Long-term profile changes in extraction and nonextraction patients. Am J Orthod Dentofacial Orthop. 2005 Oct;128(4):450-7.

24. Tadic N, Woods MG. Incisal and soft tissue effects of maxillary premolar extraction in Class II treatment. Angle Orthod. 2007 Sep;77(5):808-16.

25. Türkkahraman H, Gökalp H. Facial profile preferences among various layers of turkish population. Angle Orthod. 2004 Oct;74(5):640-7. 